\title{
A NOTE ON "TACIT UNIVERSAL PARTNERSHIPS": CLARITY AT LAST: EX-PARTNER CAN GET SLICE OF THE PIE
}

\section{Introduction}

There is no assumption of marriage in South African law in consequence of cohabitation regardless of the duration of the relationship. Our law does not give automatic rights to partners in a cohabitation relationship. If one of the parties dies without leaving a will for instance, the domestic partner is not legally entitled to inherit or to claim maintenance from the deceased's estate. An aggrieved party would have to go to court to show that the parties were partners in a "universal partnership" and that the one party owes something to the other. The question that often arises is whether any mechanisms exist for the division of assets accumulated in a cohabitation situation on separation of the parties. If parties have cohabited and they can prove that a tacit universal partnership exists between them, all property of such a partnership is deemed to be jointly owned by the parties and debts are the joint liability of the parties. The issue as to whether a tacit universal partnership extends beyond commercial undertakings and whether the contribution by each party must be confined to profit-making has been the subject of much debate by our courts but has finally been decided by the court in the cases of Ponelat $v$ Schrepfer (2012 (1) SA 206 (SCA)) and Butters v Mncora (181/2011) [2012] ZASCA 29 (28 March 2012)).

\section{A constitutional perspective}

The general rule of our law is that cohabitation does not give rise to special legal consequences (Sinclair and Heaton The Law of Marriage Vol 1 (1996) 274). In Volks NO v Robinson (2005 (5) BCLR 446 (CC)) the court held that the supportive and protective measures established by family-law are generally not available to those who remain unmarried, despite their cohabitation, even for a lengthy period. A cohabitee can, however, invoke one or more of the remedies available in private law, provided, of course, that he or she can establish the requirements for that remedy. In this case, the couple lived together for years without validly marrying despite there not being any legal impediment to such a marriage. After the man's death, the surviving cohabitant instituted a claim for maintenance against the deceased cohabitant's estate in terms of section 2(1) of the Maintenance of Surviving Spouses Act 27 of 1990. The court rejected the claim on the basis that the parties had never been validly married and that she did not qualify as a "spouse" in terms of the statute. The court a quo, the Cape High Court, held that the surviving cohabitant could institute a claim for maintenance against the deceased party's estate, as the statute discriminated unfairly against her based on marital status. As such, it violated the right to equality and dignity 
thereby rendering it unconstitutional (Robinson v Volks NO 2004 (6) SA 288 (C) / 2004 (2) All SA 61 (C)).

The Constitutional Court disagreed and refused to confirm the finding that the statute was unconstitutional. The majority of the court was prepared to accept that there was prima facie discrimination based on marital status. He found that marriage is an important institution: an "intentionally recognised social institution" (par [53]) that afforded benefits to married people to which unmarried people would not be entitled. He noted that there were fundamental differences between the position of a surviving cohabitant and that of a surviving spouse. Their choice of relationship determined the formalities and the legal consequences.

The court found that the discrimination between the type of relationships was fair "when considered in the larger context of the rights and obligations uniquely attached to marriage" (par [61]). In addition, as the parties have a choice to conclude a marriage or not, there is no violation of the respondent's right to dignity. In light of the importance of the institution of marriage, it would be inappropriate to impose a duty of support on a deceased estate when such a duty had never arisen while both parties were alive. In fact, to do so would be "incongruous, unfair, irrational and untenable" (par [60]). Two years later the Constitutional Court in Gory v Kolver NO (2007 (4) SA 97 (CC)) somewhat altered their position by finding that section 1(1) of the Intestate Succession Act 81 of 1987 may be unconstitutional to the extent that it only provided for spouses to a marriage to inherit intestate. It found that this statute must be read to include, after the definition of the word "spouse", "partner" in a permanent same-sex life partnership in which the parties have undertaken reciprocal duties of support. The court did not address the issue of heterosexual life partnerships.

\section{$3 \quad$ Historical perspectives on universal partnerships}

Our courts have accepted the formulation by Pothier as to the essential elements of a partnership (Pothier $A$ Treatise on the Law of Partnership (2004) (Tudor's Translation 1.3.8)). These essentials are firstly, that each of the partners brings something into the partnership, or binds him- or herself to bring something into it, whether it be money, or his/her labour or skill. The second element is that the business should be carried on for the joint benefit of both parties. The third is that the object should be to make a profit. Finally the contract between the parties should be a legitimate contract. Where all these four elements are present, in the absence of something indicating that the contract between the parties is not an agreement of partnership, the court must come to the conclusion that it is a partnership. It makes no difference what the parties have chosen to call it, whether they call it a joint venture, or letting and hiring. The court must decide what is the real agreement between them. These elements for the valid existence of a partnership have been consistently approved by our courts (Joubert $v$ Tarry \& Co 1915 TPD 277 279; Rhodesia Railways v Commissioner of Taxes 1925 AD 438 464-465; Bester v Van Niekerk 1960 (2) SA 779 (A) 783H784A; Mühlmann v Mühlmann 1981 (4) SA 632 (W) 634C-F; and Pezzutto v Dreyer 1992 (3) SA 379 (A) 390A-C). 
It is important to note that the fourth element by Pothier has been discounted by our courts as being common to all contracts (Bester $v$ Van Niekerk supra 784A). As was pointed out by Schreiner $\mathrm{J}$ in Delyannis $v$ Kapousousoglu (1942 (2) PHA 40):

"illegality as a ground of invalidation seems to be part of the general law of contract; as such it does not seem to me to be convenient to include it in a category of the essentials of partnership".

The courts have stated that in order for the partnership to be classified as a universal partnership the parties must agree to put in common all their property, both present and future (Isaacs $v$ Isaacs 1949 (1) SA 952 (C) 955; and Sepheri v Scanlan 2008 (1) SA 322 (C) 338C-D. See also Ally v Dinath 1984 (2) SA 451 (T)).

The court in Isaacs $v$ Isaacs (supra 956) held that the essentials of a partnership set out above apply equally to a universal partnership (see also Mühlmann v Mühlmann supra; V (aka L) v De Wet NO 1953 (1) SA 612 (O) 615; and Schaeffer Family Law: "Cohabitation" (2001-2002) 3; and Festus V Worcester Municipality C 1945 CPD 186 (C).

There is, however, support for the view that in terms of historical research, first published in 1980 and then even more recently that Isaacs $v$ Isaacs (supra) was based on a faulty premise (see Henning "Die Leeuevennootskap: Aspekte van Deelname in Wins en Verlies deur Vennote" 1980 Modern Business Law 147; see also 17th century Roman Dutch authority of Felicius-Boxelius Tractatus de Societate, translated by Henning, Wessels and De Bruyn Perspectives on and a Selection from Felicius-Boxelius Tractatus de Societate a Treatise on the Law of Partnership (2006)).

It is accepted that, apart from particular partnerships entered into for the purpose of a particular enterprise, Roman and Roman Dutch law also recognized universal partnerships. Within the latter category, a distinction was drawn between two kinds. The first was the societas universorum bonorum - also referred to as the societas omnium bonorum - by which the parties agree to put in common all their property present and future (Tudor's translation 24). The second type consisted of the societas universorum quae ex quaestu veniunt - the parties thereby contract a partnership of all that they may acquire during its continuance, from every kind of commerce. They are considered to enter into this kind of partnership when they declare that they contract together a partnership without any further explanation (Tudor's translation 32).

In the past South African courts have expressed the view that that universal partnerships of the first kind, that is, those including all property, were not allowed save between spouses and perhaps in the case of putative marriages (see eg, De Wet and Yeats Kontrakte- en Handelsreg 3ed (1964) 565; and Bamford The Law of Partnership and Voluntary Association in South Africa 3ed (1982) 19; Isaacs v Isaacs (supra 955); V (aka L) v De Wet NO supra). Moreover, the perception was that even where a partnership of all property was allowed, it required an express agreement and could therefore not be brought about tacitly (Annabhay v Ramlall 1960 (3) SA 802 (D) 805E). 
The Roman-Dutch authorities relied upon for these propositions were primarily De Groot (Inleidinge 3.21.3) and Voet (Commentarius ad Pandectas 17.2.4). What the historical research published in 1980 revealed, however, was that De Groot and Voet were contradicted by others, such as Pothier ( $A$ Treatise on the Law of Partnership 7.2.79-81) and Van Leeuwen (Rooms-Hollandsch Recht 4.23.1-2), who dealt with universal partnerships of all property at some length as being usual and valid in Roman Dutch law (see Henning Law of Partnership (2010) 24-27 and the authorities there cited). Most explicit in this regard appears to be Felicius-Boxelius (Perspectives on and a Selection from Felicius-Boxelius 10.15) who stated the position as follows:

"There are some jurists who maintain that a societas omnium bonorum cannot be entered into tacitly ... but that ... for all the assets to be brought into the partnership it is necessary that the societas omnium bonorum be entered into expressly. [B]ut there are other jurists who hold the contrary view: that a societas omnium bonorum may surely be entered into tacitly by performing an act of partnership, because it is that type of contract which can be entered into by consensus alone and the validity of tacit and express partnerships is the same."

The most problematic of the requirements seems to be the second required laid down by Pothier that the venture is carried out for the joint benefit of both the parties and not just for the benefit of the partner that is directly involved in the profit-making venture/ business at the time. However, the problem in most of the cases seems to be related to evidence of the intention of the parties to create this partnership within the context of their chosen lifestyle. In a number of recent judgments, the issue of permanent heterosexual life partnerships became the focus of the courts. In all these matters, there was a claim by one of the cohabitants after the dissolution of the relationship. In these cases, the applicants based their claims on the concept of a universal partnership entered into through a tacit agreement between the parties.

In each the cases were obviously decided on the facts itself.

\section{$4 \quad$ Case law}

In the cases of McDonald $v$ Young (2012 (3) SA 1 (SCA)) and Francis $v$ Dhanai ([2006] JOL 18401 (N)) the applicants were unsuccessful. In McDonald $v$ Young (supra) the parties had lived together as husband and wife for seven years when the marriage had broken down. The appellant did not have any meaningful assets and had a really limited income. The wife on the other hand, had accumulated considerable wealth at her own expense. The appellant claimed that he was entitled to a half share of the property. $\mathrm{He}$ alleged that the parties had entered into an express oral joined-venture agreement in terms of which the respondent would contribute financially to the acquisition, completion and refurbishment of the property and that he will contribute his time and expertise to the development of the property. In the alternative, the appellant claimed that the respondent was under a duty by virtue of a tacit contract to support him subsequent to their cohabitation (par [1]-[2]). 
The Supreme Court of Appeal (SCA) held that the appellant's claim in regard to the joint-venture agreement was contrary to all reasonable probabilities. The appellant's claim for maintenance was dismissed as there was no reciprocal duty of support on the parties/cohabitants. The court held further that it could not infer a tacit contract from the proved facts. This was so because such a conclusion would conflict with the appellant's evidence that the alleged joint-venture agreement was intended to ensure that he gained financial independence (par [25]-[26]).

In Francis $v$ Dhanai (supra) the plaintiff stated that she and the defendant had lived together as man and wife from May 1992 until February 2002. She argued that during this period both she and the defendant had contributed equally to the acquisition of assets and payment of liabilities. The plaintiff alleged that during or about August 1992, both the plaintiff and the defendant had entered into a universal partnership in terms of an oral agreement alternatively a tacit agreement (1). In terms of the abovementioned agreement the plaintiff undertook to conduct a home industry from their residence, hand the income to the defendant to be utilized for the maintenance of the joint household, contribute to the purchase of the immovable property and support the defendant financially when he was unemployed (2).

The plaintiff alleged that both parties had contributed labour, services, money and skills to the partnership. That their income was utilized to maintain the joint household and to acquire assets. The conduct of the parties thus constituted a universal partnership to which both parties contributed in equal shares. The plaintiff alleged that both she and the defendant had lived together as man and wife and contributed equally to the acquisition of assets and payment of liabilities. The plaintiff argued that she was entitled to $50 \%$ of the net assets of the marriage (2).

The defendant denied the existence of a universal partnership and he argued that the plaintiff had lived with him in his home merely because she was destitute and he provided her with food and shelter out of benevolence, and that any cohabitation between them was not the equivalent of that between man and wife. It was according to the defendant a relationship of convenience; that there was no joint household and the plaintiff had not contributed anything towards his estate, as she had no income, because she was in receipt only of a disability grant, alternatively because she was unemployed; the plaintiff had no way contributed to the purchase of his immovable property; that he at no stage intended to marry the plaintiff nor had they at any stage contemplated a universal partnership and never was a universal partnership expressly or tacitly entered into (2-3).

The court held that the evidence satisfied the court that a factual relationship existed between the parties. The question was whether a universal partnership had existed. The court discussed the requirements for the establishment of the existence of an universal partnership. After discussing the requirements the court concluded that the plaintiff had failed to prove on the balance of probabilities the following essential elements of alleged universal partnership: the existence of a joint-venture or commercial enterprise; a consensual contract to enter into the venture; the exact terms 
of the partnership; and the exact assets that were acquired by the partnership. The court dismissed the plaintiff's claim with costs.

In JW v CW (2012 (2) SA 529 (NCK)), a wife who was being sued for divorce sought a declaratory order that a universal partnership existed between her and her husband. The spouses had married in 1992. Their antenuptial contract not only provided for complete separation of property (that is, marriage out of community of property with exclusion of the accrual system) but also provided that they would act in the spirit of the contract in so far as their property was concerned. The wife alleged that, shortly after marrying, the parties had tacitly entered into a universal partnership and that the partnership assets encompassed all their movable and immovable assets. The husband's legal representative alleged that the wife was seeking to prove the existence of a universal partnership in the form of a partnership universorum bonorum (that is, a universal partnership relating to all the assets of the parties), and that such a partnership offended the express terms of the spouses' antenuptial contract. Procedural issues arose regarding the wife's claim, but those issues are unimportant for present purposes. This discussion below focuses only on the issue of whether the alleged universal partnership could have come into existence.

Olivier $\mathrm{J}$ pointed out that a universal partnership may take one of two forms - a partnership universorum bonorum or a partnership universorum quae ex quaestu veniunt (that is, a universal partnership that is limited to assets acquired from the partners' engaging in commercial activities) (par [9]). The wording and implication of the wife's pleadings indicated that the type of universal partnership she alleged existed between the spouses was a universal partnership universorum bonorum. Such a universal partnership was irreconcilable with the terms of the spouses' antenuptial contract (par [15] and [19]). However, even if the wife had contended for a partnership universorum quae ex quaestu veniunt her contention would have been irreconcilable with the terms of the antenuptial contract, for the contract did not distinguish between existing and future property and did not provide for complete separation of property only in respect of some assets; it established complete separation of property in respect of all assets and also provided that the spouses had to act in the spirit of such exclusion (par [12], [15], [20] and [23]). Olivier $\mathrm{J}$ stated that earlier cases in which it had been held that spouses who were married out of community of property might enter into a universal partnership related only to the partnership universorum quae ex quaestu veniunt (par [33]-[34]) The judge further warned that even though spouses who were married out of community might enter into a universal partnership, the specific terms of a particular antenuptial contract might exclude a future partnership (by whatever name it might be called) if the terms of the particular partnership would contradict the antenuptial agreement' (par [24]). This was the situation in the present case.

Olivier $\mathrm{J}$ held that the universal partnership the wife sought to prove would in effect amount to a marriage in community of property, defeat the clear purpose of the antenuptial contract, and not be in the spirit of the antenuptial contract (par [22] and [25]). The agreement to establish a universal partnership would therefore amount to a revocation or variation of the essence of the antenuptial contract (par [29]). Such revocation or variation 
had to have been authorized by a court (par [30]). As a result, Olivier $\mathrm{J}$ held that evidence in substantiation of the wife's allegations regarding the universal partnership would be inadmissible (par [42]).

In view of the particular terms of the antenuptial contract and the way in which the pleadings were framed, Olivier J's views on the wife's claim regarding a universal partnership universorum bonorum were supported (see also Adcock $v$ Adcock (3617/09) [2012] ZAECPEHC 28 April; Smalberger $v$ Stols $(1112 / 2102)$ [2012] ZAECPEHC 13-, where the plaintiff failed to establish that a universal partnership existed between herself, the Trust and her husband).

There are cases were the applicants have been successful and the requirements for a tacit universal partnership have been satisfied and it made no difference to the court whether the parties were married, engaged or cohabiting.

The case of Botha NO v Deetlefs (2008 (3) SA $419(\mathrm{~N}))$ dealt with the application for the ejectment of the first respondent (par [1]). The applicant was the executor of the estate of her deceased father. The first respondent, a major female was in a relationship with the deceased over a considerable amount of time. The deceased and the first respondent lived together until the death of the deceased. The second respondent was the Master against whom no relief was claimed (par [2]).

The first respondent contended that since 1999, when she commenced living with the deceased, there existed a tacit universal partnership between her and the deceased. She issued summons out of this division and sought an order declaring that a universal partnership existed, declaring that it was dissolved by the death of the deceased; for an order appointing a receiver to take charge of and realize the assets of the partnership; demand true and correct amount of a portion of the assets in which others might have taken possession; discharge the liabilities and debts of the partnership and divide the partnership equally between the estate of the deceased and the first respondent (par [5]).

The first respondent claimed that she and the deceased administered a joint household since 1999, when they combined their lives and possessions. She claimed that she contributed to the expenses of running the household and also contributed to the mortgage bond instalments (par [6]). The court held that any such partnership would have terminated ex lege upon the depth of the deceased, and the court held further that an absence of any agreement or unilateral undertaking by the deceased making over the property to the respondent, a former partner could not remain in exclusive possession and occupation of the partnership asset to the exclusion of the other partner or his deceased estate. The court held that the respondent only had the right to an undivided half share in the partnership which was not necessarily co-extensive with a half share in immovable property of the deceased estate (par [14]-[19]). The court granted the application sought by the applicant.

The court in Ponelat $v$ Schrepfer (supra) dealt with an appeal from a judgment in the Eastern Circuit Local Division of the High Court in terms of which the court found that a tacit universal partnership agreement existed 
between the parties, the plaintiff's shares therein being 35\% and that of the defendant, $65 \%$ (1-3 of the judgment). During the course of the proceedings in the court a quo (before Chetty J), the plaintiff, abandoned her alternative claim for contractual damages. All that remained at the end of the proceedings in the court a quo were the plaintiff's claim based on the existence of a universal partnership and her delictual claim for damages resulting from the defendant's breach of promise to marry her.

Chetty $\mathrm{J}$, in the court a quo decided that a tacit universal partnership did in fact exist between the parties. He then determined the plaintiff's share in the partnership at $30 \%$ and awarded her an amount equal to that percentage of the defendant's net asset value as at the date when the partnership came to an end. On the plaintiff's second claim Chetty $\mathrm{J}$ awarded her delictual damages for breach of promise in an amount of R25 000 (par [3]). The defendant's appeal was confined to the judgment on the plaintiff's first claim. No question was raised with regard to the percentage of the defendant's estate awarded to the plaintiff.

The only issue to be decided on appeal was whether a tacit universal partnership existed between the parties. The plaintiff moved into the defendant's home where they lived together as man and wife sharing a joint household. The plaintiff had sold her furniture and car, and the proceeds were made available to the joint household. In addition she contributed her earnings to the joint-household expenses. The plaintiff also carried out domestic work and assisted in the administration of the defendant's business. The SCA held that, based on the evidence and the nature of the discussions between the parties prior to their cohabiting and their intent during the 16 years together, they had the requisite intention to form a universal partnership. The plaintiff came to the relationship on the basis that the defendant would give her what was his and she would give him what was hers. There was the promise of security. And during the 16 years together the parties did pool their assets and resources. The plaintiff contributed all she had financially and physically, the proceeds of the sale of assets, her salary, time, energy, labour, skills and expertise. The court held that the conduct of the plaintiff was that which can ordinarily be expected from a wife and was not simply that which is ordinarily to be expected of a cohabitee. The defendant contributed his business, financed the various properties and provided financial security. The court held that the pooling of the resources, the joint investment were all indicators of the existence of a universal partnership. Activities engaged in by the parties were for their joint benefit and the increase of their assets (par [23]).

In Butters v Mncora (supra) Mr Butters, the "defendant" and Ms Mncora, the "plaintiff" as cited in the court a quo had lived together as husband and wife for almost 20 years. They never married. They were engaged to be wed for almost ten years, although this never happened. The relationship came to an end on New Year's day 2008. The plaintiff was born in 1964. After she matriculated, she enrolled for a course in business administration. She met the defendant during 1988 when she was 24 and he was 27. During this time she lived with her parents in Port Elizabeth while he lived and worked in Grahamstown. The defendant worked as a technician for the post office, which later became Telkom. The parties visited each other regularly over 
weekends, either in Port Elizabeth or Grahamstown. In time they became intimate and a child was born from their relationship in January 1991 (par [5]).

While the defendant continued to work at the post office he started to install alarm systems in houses and cars in his spare time, for extra income. During the week he did so in Grahamstown after hours, and over weekends in Port Elizabeth. It was the plaintiff's testimony that she assisted him in installations by "giving him some stuff and wires that he wanted" and also by introducing him to prospective clients (par [5]).

In June 1992 the defendant resigned from the post office and started a security business under the name Hitech. The plaintiff continued to live in Port Elizabeth, but the parties decided that the business should be established in Grahamstown where there was less competition. The business grew and the defendant built a house in Port Elizabeth where the plaintiff moved in together with their son and her daughter from a previous relationship, whom the defendant maintained and treated as his own. In 1994 the plaintiff started working as a secretary with the Department of Education at a salary of R2 000 per month, but she soon stopped working after two years because the plaintiff wanted her to stay at home with the children (par [6]).

In 1998 the defendant proposed to the plaintiff and gave her an engagement ring. On 7 January 1999 the plaintiff gave birth to their second son. In 2004 the defendant's daughter from a previous relationship also took up residence with them, so as to enable her to receive a better education in Port Elizabeth. She stayed for three years until she matriculated in 2007. The defendant's business continued to grow and so did the family lifestyle. They moved into a house with four bedrooms and a swimming-pool; they employed a full-time domestic worker; expensive family holidays were undertaken; and the children went to expensive private schools. The defendant was a good provider and the plaintiff took responsibility for raising the children and maintaining their common home, which the defendant visited over weekends (par [7]).

The defendant had over a period of time acquired many assets. The "common home" and all other immovable properties so acquired were registered in his name. The plaintiff maintained that her understanding was that all the assets and belongings were to be shared and that neither the plaintiff nor the defendant had claimed exclusive ownership of any item. According to his testimony the defendant maintained that whatever he acquired was his and his alone (par [8]).

The plaintiff did concede that she did not contribute anything with regard to the Hitech business after it had been established in Grahamstown and that she in fact never entered the premises of this business. Her position was that, while she had made no direct contribution to the defendant's business, she supported him, cared for him and the children and maintained their common home. The defendant contested this on the grounds that the plaintiff played no part in his business life; that he was the only one who earned any income while she brought up the children and paid the household expenses with money provided by him (par [9]). 
The relationship started to breakdown in 2006. In 2007 the plaintiff then noticed changes in the defendant's behaviour in that he started spending less time with his family in Port Elizabeth. The deterioration of the relationship culminated on the evening of New Year's day 2008. The plaintiff and the children unexpectedly returned home to find the defendant with another woman, one Ms Mbewu. It is then for the first time the plaintiff became aware that the defendant had married Ms Mbewu on 15 November 2007. The relationship between the defendant and the plaintiff came to an abrupt end as result of this incident. The termination of the relationship left the plaintiff unemployed and without any personal income at the age of 44 (par [10]). The only question for determination on appeal was whether there existed a tacit universal partnership between the parties.

The plaintiff cited the statement by Felicius-Boxelius (Perspectives on and a Selection from Felicius-Boxelius 10.17) (referred to by Henning Law of Partnership) with regard to the requirements for a universal partnership of all property between cohabitees, as part of South African law:

"I would like to add that for this type of contract to be presumed there are three interlinked prerequisites; namely cohabitation, sharing of profits and freedom of accounting to each other."

The court was not willing to accept this statement as the requirements for a partnership as formulated by Pothier had been well-established as part of our law. They have been applied by our courts to universal partnerships in general and universal partnerships between cohabitees in particular. Thus there was no need to formulate special requirements for the latter category. This was also borne out by the fact that Pothier himself did not find his formulation of the requirements incompatible with the concept of universal partnerships of all property which he discussed in some detail (par [17]). These requirements have been approved and applied either expressly or by implication in the vast majority of South African cases when dealing with the issues in question (see Ally $v$ Dinath supra 453F-455A; Mühlmann $v$ Mühlmann supra 634A-B; Mühlmann v Mühlmann 1984 (3) SA 102 (A) 109C-E; Kritzinger v Kritzinger 1989 (1) SA 67 (A) 77A; Sepheri v Scanlan supra 338A-F; Volks NO v Robinson supra par 125; Ponelat $v$ Schrepfer supra par 19-22; see further Henning Law of Partnership 20-29; and LAWSA 2ed par 257).

Once it was accepted that a partnership enterprise might extend beyond commercial undertakings the court was of the view that the contribution of both parties need not be confined to a profit-making entity. In Butters $v$ Mncora (supra), it can be accepted that the plaintiff's contribution to the commercial undertaking conducted by the defendant was insignificant. The plaintiff, however, spent her time, energy and effort taking care of the communal home, and rearing the children. On this basis that the partnership enterprise between the plaintiff and the defendant could include a commercial undertaking and the non-profit making part of their family life, for which the plaintiff took responsibility, her contribution to that notional partnership enterprise can hardly be denied (par [19]).

The defendant contended that the plaintiff had failed to fulfil the second element by Pothier that the partnership enterprise had to be carried on for 
the joint benefit of both parties. There was never an express partnership agreement or any formal agreement that the parties would share the profits or assets. The contention that everything was to be shared was based solely on the plaintiff's own understanding. The plaintiff's impression was never questioned or suggested to her that this impression was unfounded under cross examination (par [20]).

The defendant argued that he had earned all the income and therefore he had a right to retain everything he acquired from his own income. The defendant did concede that if both parties had earned an income in which they then shared, the plaintiff would have gone a long way in meeting the second requirement by Pothier. The court stated that the plaintiff's case was not that she and the defendant had entered into a commercial partnership which was confined to the Hitech business. Her case was that they had entered into a partnership which encompassed both their family life and the business conducted by the defendant. The court had considered the truth of the plaintiff's proposition that they tacitly agreed to share everything, including the income of the business conducted by the defendant. In this regard the court did not have to consider partnerships as being confined to commercial enterprises but rather the contribution of persons (in this case the plaintiff) who were prepared to sacrifice the satisfaction of pursuing their own careers, in the best interests of their families (par [21]-[23]).

The defendant relied on the proposition in cases such as Du Toit $v$ Minister for Wellfare and Population Development (2003 (2) SA 198 (CC)) and Volks $v$ Robinson (supra) that the position of cohabitees should not be identified with that of spouses married in community of property. The Constitutional Court had in these cases recognized the importance of marriage as a social institution, which was not to be equated with mere cohabitation. Brand JA, held that in his view a universal partnership was not the same as a marriage in community of property and therefore the defendant's argument could not be sustained (see Henning Law of Partnership 30; and see also Hare v Estate Hare 1961 (4) SA 42 (W) 44G-45D).

The defendant did not argue that the third requirement by Pothier had not been satisfied. This was the correct approach according to Brand JA. This was so because all the evidence indicated that the all-embracing venture pursued by the parties, which included both their home life and the business conducted by the defendant, was aimed at a profit which the parties had tacitly agreed to share (par [31]).

Brand JA, (Mhlantla JA, and Tshiqi JA concurring) held that it was clear that the defendant shared in the benefits derived from the plaintiff's contribution. This was so, because according to the learned Judge there was no evidence that during the short period of two years when the plaintiff earned an income she applied those earnings for herself. The indications were that she shared that income with the defendant. Brand JA held that of greater significance was that in that case the defendant shared the benefits of the plaintiff's contribution to the maintenance of their common home and the raising of the children. This was even more evident in the fact that the plaintiff was not only prepared to take responsibility for the children of the parties, but also for the defendant's daughter from a previous relationship. 
There was nothing according to the court that the plaintiff could have done to further promote the family life over the last 20 years (par [24]).

The plaintiff had shared in the benefits of the defendant's financial contribution. The defendant's contention that she paid the household expenses with money supplied by him confirms this fact. The defendant had to pay for everything because the plaintiff had no earnings of her own. The contribution by both parties, be it financial or otherwise, was shared and consumed in the pursuit of their common enterprise (par [25]).

On the basis of the decision in South African Forestry Co Ltd $v$ York Timbers Ltd (2005 (3) SA 323 (SCA) 32), Brand JA held that the court was well entitled to proceed on the basis that evaluating the conduct of the parties, that they were dealing with each other in good faith. This was so, because the parties lived together in an intimate relationship in which they shared their most personal interests for almost 20 years. The unexpressed reservation on the part of the defendant, that he was willing to share in the benefits derived from the plaintiff's contribution, but not in the surplus fruits of his own, would not be in keeping with the dictates of good faith The court was thus satisfied that the plaintiff had succeeded in establishing Pothier's second requirement for a partnership (par [27]).

The defendant argued that the plaintiff did no more than could be expected of a cohabitee. The defendant relied on the statement, made in the context of parties married out of community of property, in Mühlmann $v$ MühImann (supra 124D-E), where the stated the following:

"It is, of course, well known ... that many wives work in the businesses of their husbands without expecting or receiving any remuneration for their services.

From this it follows that, unless a wife had rendered services manifestly surpassing those ordinarily expected of a wife in her situation, a Court will not easily be persuaded to infer a tacit agreement of partnership between the spouses."

The court held in this case that there were well established social and legal standards that govern and regulated marriages which provided a good idea of what might be expected of a wife in the situation of the plaintiff but such could not be transposed to a relationship between cohabitees. Thus this argument did not assist the defendant's case (par [29]).

The appeal was accordingly dismissed with costs including the costs of two counsel.

It is worth noting that Heher JA (Cachalia JA concurring) expressed a dissenting judgment in that case. Heher JA stated that in his view that was essentially an appeal about a tacit agreement. In such cases a court would search the evidence to establish what was the conduct of the parties and whether the conduct was consistent with consensus on the issue. According to Heher $\mathrm{J}$ in order to prove that the tacit agreement that was relied on was one of universal partnership both parties had to have intention to share in the profits of the subject matter. In that instance by far the most significant contributory factor to the "partnership" estate was the business started, managed and brought to a substantial level of success by the defendant alone during the cohabitation of the parties (par [34]-[36]). Heher JA held that when parties cohabited in a state of amity over a long period, as in that 
case it was likely that certain things would happen: the principal breadwinner would contribute substantially, either regularly or on an ad hoc basis, to the needs of the family by providing accommodation, food, clothing, education, transport and health care. To these would usually be added vacations and presents of various kinds. The other party, usually the woman, would stay at home or engage in lesser employment and oversee the needs of the family and the upbringing of the children. These according to Heher JA are the normal incidents of cohabitation, just as they were of marriage. That they happened in the case under consideration contributed nothing to the present enquiry because they were at best equivocal and they absented of some evidential feature that linked them to the special intention that attached to a universal partnership (par [37]).

The contribution of the plaintiff according to Heher JA was of a short duration and not of enduring benefit. There was no evidence of either interest or participation in the defendant's work or his fruits (par [39]). Heher JA held that the plaintiff did not produce anything that established an intention on her part to share in the defendant's estate. The appellant said and did nothing to treat the respondent as other than an ad hoc recipient of the fruits of his labours according to his own generosity at any given time. According to Heher JA, a "cohabitee" could not claim a share in his/her partner's estate just because he/she would otherwise be "left with nothing" (par [44]).

\section{Conclusion}

It has now become clear that in light of the judgment of the courts in Ponelat $v$ Schrepfer (supra) and Butters v Mncora (supra) that our courts have now confirmed either expressly or by implication that universal partnerships of all property which extend beyond commercial undertakings were part of Roman-Dutch law and still form part of our law, and that a universal partnership of all property does not require an express agreement. Like any other contract it can also come into existence by tacit agreement, that is by an agreement derived from the conduct of the parties. It is also clear that the requirements for a universal partnership of all property, including universal partnerships between cohabitees, are the same as those formulated by Pothier for partnerships in general. In situations where the conduct of the parties is capable of more than one inference, the test to determine the existence of a tacit universal partnership is whether it is more probable than not that a tacit agreement had been reached.

Darren Subramanien

University of KwaZulu-Natal, Pietermaritzburg 